\title{
The outcomes of becoming a pediatric burn center in Turkey
}

\author{
Can İhsan Öztorun, M.D., Sabri Demir, M.D., Müjdem Nur Azılı, M.D., \\ Atilla Şenaylı, M.D., Ziya Livanelioğlu, M.D., Emrah Şenel, M.D.
}

Department of Pediatric Surgery, Ankara Pediatric Hematology, Oncology Training and Research Hospital, Ankara, Turkey

\begin{abstract}
BACKGROUND: Burns are one of the most important causes of traumatic death in children worldwide. A pediatric burn center was established in our hospital in August 2009. The aim of this study was to compare patient profiles and data before and after the burn treatment center was established.

METHODS: Burn patients were admitted to the pediatric surgery department between January 2005 and August 2009 , and there was no intensive care service in this department. Intensive care service has been provided since August 2009 with the burn center established at our hospital. The 316 cases that were followed-up at the pediatric surgery department in the first period were identified as Group I and the 442 cases that were admitted to the burn center in the second period were identified as Group II. The data of the groups were then compared.
\end{abstract}

RESULTS: Mean age of the cases was 5.1 years in Group I and 7.7 years in Group II. The total mean body burn percentage was $16.12 \%$ in Group I and 17.54\% in Group II. Although scalding burns were the most subtype in both groups, flame burns were 2.13 times, electrical burns 3.44 times, flame+inhalation burns 8.33 times, and burns with an over $40 \%$ total burn surface area were $2.4 \mathrm{I}$ times more common in Group II than in Group I. The mortality rates were 0\% in Group I and 2.26\% in Group II.

CONCLUSION: Converting to a normal department admitting burn patients in a burn unit format to an actual burn center means more severe cases will be admitted. This requires a patient and attentive process while the burn team struggles with the new patient profile on one hand and has to learn how to overcome with less personal trauma the loss of patients, a feeling it is unfamiliar with, on the other, which is also an actual training process for the entire burn team.

Key words: Burn center; mortality; pediatric burns.

\section{INTRODUCTION}

Pediatric burns continue to be one of the most important community health problems in developed and developing countries. Burn centers with the necessary physical facilities, technological equipment and trained health care staff to take care of such patients play a critical role in burn treatment. The Turkish Ministry of Health has been trying to establish pediatric burn centers with trained health care staff equipped to intervene in severe burns in our country for the last few years. The Ankara Child Health and Diseases Hematology

Address for correspondence: Can İhsan Öztorun, M.D.

Ankara Çocuk Sağlığı ve Hastalıkları Hematoloji, Onkoloji Eğitim ve Araştırma Hastanesi, Çocuk Cerrahisi Kliniği, Ankara, Turkey

Tel: +90 312 - 5969884 E-mail: canoztorun@mynet.com

Qucik Response Code

Ulus Travma Acil Cerrahi Derg

2016;22(1):34-39

doi: $10.5505 /$ tjtes.2015.46417

Copyright 2016

TJTES and Oncology Training and Research Hospital's Pediatric Burn center was established in August 2009 within this framework. Burn patients were being hospitalized and treated at the pediatric surgery department previously. The aim of this study was to compare the profiles and results of the cases followed up after admission to the pediatric surgery department or the pediatric burn center.

\section{MATERIALS AND METHODS}

There were three hundred and sixteen cases hospitalized and treated at the pediatric surgery department between January 2005 and August 2009, whowere included in Group I, and there were four hundred and forty-two cases hospitalized and treated at the burn center between August 2009 and March 2013, who wereincluded in Group II. The data of these seven hundred and fifty-eight children were compared by groups. The data in the hospital automation system, hospitalization records, patient charts, and surgical notes were evaluated for this purpose. The data of the groups were sta- 
tistically compared. The Mann-Whitney and Chi-Square tests were used for statistical analysis. A p value 0.05 was accepted statistically significant.

\section{RESULTS}

A total of three thousand and forty-seven burn cases between the ages of 0 and 18 years presented to our hospital between January 2005 and August 2009 and seven hundred and fiftyeight were hospitalized and treated. The three hundred and sixteen hospitalized Group I patients were treated between January 2005 and August 2009 in the pediatric surgery department and the four hundred and forty-two hospitalized Group II cases were treated between August 2009 and January 2013 in the burn center. The mean age was 5.1 years \pm 8.7 SD in Group I and 7.7 years \pm I3.2 SD in Group II. There were $448(59.1 \%)$ males and 310 (40.9\%) females. The male/ female ratio was $\mathbf{I . 4 4}$. There was no statistically significant difference between the groups in terms of age or gender. The distribution of the cases by group is presented in Table I.

The mean number of patients hospitalized per year was 70.22 in Group I and I 26.28 in Group II. Referrals from outside Ankara made up 17.1\% of Group I patients and 31.2\% of Group II patients. Our clinic admits burn patients from many different provinces. A statistically significant difference was present between the groups in terms of patients who were referred from outside the province $(p<0.01)$. An air ambulance was not used for any Group I patient but nineteen (4.2\%) Group II cases required this way of transport.

None of the Group I cases arrived intubated but there were thirty-two (7.22\%) such cases in Group II. A statistically significant difference was present between the groups $(p<0.01)$. The mean presentation time was 9.24 hours in Group I and 24.42 hours in Group II. There was a statistically significant

Table I. Demographic data by patient group

\begin{tabular}{lccc}
\hline & Group I & Group II & Total \\
\hline Number of patients & 316 & 442 & 758 \\
Male & $182(57.59 \%)$ & $266(60.18 \%)$ & $448(59.10 \%)$ \\
Female & $134(42.40 \%)$ & $176(39.81 \%)$ & $310(40.89 \%)$ \\
M/F & 1.35 & 1.51 & 1.44 \\
Mean age, (Mean $\pm S D)$ & $5.1 \pm 8.7$ & $7.7 \pm 13.2$ & 6.6 \\
\hline
\end{tabular}

Table 2. Data of the presentation of the patients by group

\begin{tabular}{|c|c|c|c|}
\hline & Group I & Group II & Total \\
\hline The mean number of hospitalized patients/year & 70.22 & 126,28 & 95.62 \\
\hline Mean presentation time (Hours) & 9.24 & 24.22 & 17.97 \\
\hline Number of patients Who were Referred from outside the province (\%) & $54(17.1 \%)$ & $138(31.2 \%)$ & $192(25.3 \%)$ \\
\hline Number of patients who arrived by air ambulance & 0 & $19(4.3 \%)$ & $19(2.5 \%)$ \\
\hline Number of patients who arrived Intubated & 0 & $32(7.2 \%)$ & $32(4.2 \%)$ \\
\hline
\end{tabular}

Table 3. Places of origin or referral of the patients by group

\begin{tabular}{|c|c|c|c|c|c|c|}
\hline \multirow[t]{2}{*}{ Place of origin or referral of the patient } & \multicolumn{2}{|c|}{ Group I } & \multicolumn{2}{|c|}{ Group II } & \multicolumn{2}{|c|}{ Total } \\
\hline & $\mathbf{n}$ & $\%$ & $\mathbf{n}$ & $\%$ & $\mathbf{n}$ & $\%$ \\
\hline Home & 197 & 62.3 & 84 & 19 & 281 & 37.1 \\
\hline State hospital & 81 & 25.6 & 220 & 48.8 & 301 & 39.7 \\
\hline Training and research hospital & 29 & 9.1 & 91 & 20.5 & 120 & 15.8 \\
\hline University hospital & 7 & 2.2 & 35 & 7.9 & 42 & 5.5 \\
\hline Private health institution & 2 & 0.63 & 12 & 2.7 & 14 & 1.8 \\
\hline Total & 316 & 442 & 758 & & & \\
\hline
\end{tabular}


difference between the groups $(p<0.01)$. Data on the presentation of the patients is provided in Table 2.

The majority of Group I patients had come from home while most patients in Group II had been referred from health care institutions. A statistically significant difference was present between the groups $(p<0.01)$. Data on the place of origin/ referral of the patients is presented in Table 3.

Scalding burns were most common in both groups but flame burns were 2.13 times, electrical burns 3.44 times, flame+inhalation burns 8.33 times, and burns with a total burn surface area over $40 \%$ were $2.4 \mathrm{I}$ times more common in Group II compared with Group I. The most common cause of flame burns was a tank explosion at $36.36 \%$ in Group I and flammable substances such as cologne and thinner at $78.46 \%$ in Group II. The cause of electrical burns was exposure to domestic electrical devices in 100\% of the cases in Group I and contact with a high voltage line in $50 \%$ of the cases in Group II. The relationship between the groups according to the types/causes of burn is presented in Table 4. A statistically significant difference was present between the groups according to the causes of the burns $(p<0.01)$
Hot water burns were the most common scalding burns in both groups. However, the hot water burn rate was lower and milk burn rate hwas igher in Group II compared to Group I. A statistically significant difference was present between the groups according to the cause of the scalding burn $(p<0.01)$. The causes of scalding burns by groups are presented in Table 5.

The total mean body burn percentage was $16.12 \%$ in Group I and $17.54 \%$ in Group II. There was a higher percentage of cases with a total burn area of $40 \%$ and above in Group II than in Group I. A statistically significant difference was present between the groups according to the burn area percentage $(p<0.01)$. The distribution of cases to the groups by total body burn surface area is presented in Table 6 .

Mean hospitalization duration was $11.83 \pm 13$ SD days in Group I and 18.03 10 SD days in Group II. A statistically significant relationship was present between the groups in terms of hospitalization duration $(\mathrm{p}<0.0 \mathrm{I})$.

A total of three hundred and fifty-nine $(47.3 \%)$ cases underwent debridement, II 5 (15.1\%) cases graft placement with

Table 4. Distribution between the groups according to the type and cause of the burn

\begin{tabular}{|c|c|c|c|c|c|c|}
\hline \multirow[t]{2}{*}{ Cause of the burn } & \multicolumn{2}{|c|}{ Group I } & \multicolumn{2}{|c|}{ Group II } & \multicolumn{2}{|c|}{ Total } \\
\hline & $\mathbf{n}$ & $\%$ & $\mathbf{n}$ & $\%$ & $\mathbf{n}$ & $\%$ \\
\hline Scalding & 278 & 87.9 & 342 & 77.4 & 620 & 81 \\
\hline Flame & 22 & 6.9 & 65 & 14.7 & 87 & 11.2 \\
\hline Electrical & 3 & 0.9 & 14 & 3.1 & 17 & 2.1 \\
\hline Hot object & 6 & 1.9 & 5 & I.I & 11 & 1.4 \\
\hline Flame-inhalation & 2 & 0.3 & 11 & 2.5 & 13 & 1.5 \\
\hline Chemical & 3 & 0.9 & 5 & 1.13 & 8 & 1 \\
\hline Sunburn & 2 & 0,6 & 0 & 0 & 2 & 0.2 \\
\hline $40 \%$ or above & 13 & 4.1 & 44 & 9.9 & 57 & 7.5 \\
\hline Total & 316 & & 442 & & 758 & \\
\hline
\end{tabular}

Table 5. The distribution of scalding burns according to the causes and groups

\begin{tabular}{|c|c|c|c|c|c|c|}
\hline \multirow[t]{2}{*}{ Hot liquid } & \multicolumn{2}{|c|}{ Group I } & \multicolumn{2}{|c|}{ Group II } & \multicolumn{2}{|c|}{ Total } \\
\hline & $\mathbf{n}$ & $\%$ & $\mathbf{n}$ & $\%$ & $\mathbf{n}$ & $\%$ \\
\hline Water & 250 & 89.9 & 279 & 81.4 & 529 & 85.3 \\
\hline Milk & 13 & 4.6 & 38 & 11.0 & 51 & 8.1 \\
\hline Oil & 4 & 1.4 & 3 & 0.8 & 7 & I.I \\
\hline Soup & 9 & 2.8 & 12 & 3.4 & 21 & 3.3 \\
\hline Other & 2 & 0.7 & 10 & 2.9 & 12 & 2.5 \\
\hline Total & 278 & & 342 & & 620 & \\
\hline
\end{tabular}


Table 6. The distribution of cases to the groups by total body burn surface area

\begin{tabular}{|c|c|c|c|c|c|c|}
\hline \multirow[t]{2}{*}{ TBBS } & \multicolumn{2}{|c|}{ Group I } & \multicolumn{2}{|c|}{ Group II } & \multicolumn{2}{|c|}{ Total } \\
\hline & $\mathbf{n}$ & $\%$ & $\mathbf{n}$ & $\%$ & $\mathbf{n}$ & $\%$ \\
\hline $1-19 \%$ & 209 & 66.1 & 275 & 62.4 & 484 & 64.1 \\
\hline $20-39 \%$ & 94 & 29.7 & 123 & 27.8 & 217 & 28.4 \\
\hline $40 \%$ and above & 13 & 4.1 & 44 & 9.9 & 57 & 7.5 \\
\hline Total & 316 & & 442 & & 758 & \\
\hline
\end{tabular}

Table 7. The surgical procedures used and the distribution by group

\begin{tabular}{|c|c|c|c|c|c|c|}
\hline \multirow[t]{2}{*}{ Surgical procedures } & \multicolumn{2}{|c|}{ Group I } & \multicolumn{2}{|c|}{ Group II } & \multicolumn{2}{|c|}{ Total } \\
\hline & $\mathbf{n}$ & $\%$ & $\mathbf{n}$ & $\%$ & $\mathbf{n}$ & $\%$ \\
\hline Burn debridement & 100 & 31.6 & 259 & 58.5 & 359 & 47.3 \\
\hline Burn debridement and graft & 10 & 3.1 & 105 & 23 & 115 & 15.1 \\
\hline Escharotomy and fasciotomy & 0 & 0 & 9 & 2.1 & 9 & 1.2 \\
\hline Amputation & I & 0.3 & 2 & 0.4 & 3 & 0.4 \\
\hline
\end{tabular}

debridement, 9 (1.18\%) cases escharotomy and fasciotomy and $3(0.39 \%)$ cases amputation. A statistically significant difference was present between the groups in terms of the use of surgical procedures $(p<0.0 I)$.

The relationship between the use of surgical procedures and the groups is presented in Table 7.
Mean mortality rate among all of the burn cases that presented to the hospital was $0.32 \%$. The mortality rate was $1.31 \%$ in the hospitalized patients. The mortality rate was $0 \%$ in Group I and $2.26 \%$ in Group II, with a statistically significant difference between the groups $(p<0.01)$. The mortality rates by the cause of burn are presented in Table 8 and the distribution by burn percentage in Table 9 .

Table 8. Distribution of mortality according to the cause of the burn

\begin{tabular}{lccc}
\hline Type of burn & Group I / mortality (\%) & Group II / mortality (\%) & Total mortality (\%) \\
\hline Scalding & 0 & 1.16 & 0.64 \\
Flame & 0 & 3.07 & 2.35 \\
Electrical & 0 & 7.14 & 5.88 \\
Hot object & 0 & 0 & 0 \\
Flame-inhalation & 0 & 27.27 & 25 \\
Chemical & 0 & 0 & 0 \\
Sunburn & 0 & 0 & 0 \\
\hline
\end{tabular}

Table 9. Relationship of body burn percentage, groups and mortality

\begin{tabular}{lccc}
\hline TBBS & Group I / mortality (\%) & Group II / mortality (\%) & Total mortality (\%) \\
\hline I-19\% & 0 & 0 & 0 \\
$20-39 \%$ & 0 & 1.62 & 0.92 \\
$40 \%$ and above & 0 & 18.18 & 14.03 \\
Total & 0 & 2.26 & 1.31 \\
\hline
\end{tabular}




\section{DISCUSSION}

Pediatric burns make up 36-76\% of all burn cases. ${ }^{[1]}$ However, most are small burns and are treated on an outpatient basis. About $5 \%$ of the burn cases presenting at a health center are severe and require hospital treatment. Hospitalization indications are total burn area (TBA) of $>10 \%$; hand, foot, face, perineal burns, electrical burns, and chemical burns. Causes of hospitalization vary but usually consist of fluid, flame and electrical burns. ${ }^{[2,3]}$

Our clinic is an important pediatric burn center accepting patients from many regions of the country as it is located in the capital city of Ankara. The ratio of patients referred from other cities increased from $17.1 \%$ to $31.2 \%$ after the burn center had become active in August 2009. There were also four patients referred from abroad with three from Syria and one from Afghanistan.

Burn cases that were followed-up at the pediatric surgery department between January 2005 and August 2009 and cases followed-up in the pediatric burn center between August 2009 and March 2013 were grouped and compared. The burn center had a total of 8 beds, whereas the pediatric surgery department had reserved 3 beds for these patients in the past. The mean annual number of patients was 70.22 in Group I and I26.28 in Group II. There was no statistically significant difference between the groups in terms of gender distribution and mean age. As the number of patients referred to our burn center from outside Ankara increased, the mean presentation time in Group II increased compared to Group I. This increase in presentation time was expected.

The total mean body burn percentage was $16.12 \%$ in Group I and $17.54 \%$ in Group II with no statistically significant difference between the groups. However, when evaluated in terms of body burn percentage, the rates of burns between 20 and $39 \%$ and those of $40 \%$ and above were seen twice as high in Group II compared to Group I. The reason is thought to be the increase in the number of beds and the referral of more complicated patients and those on ventilator support after becoming pediatric burn center. The mean hospitalization duration was $11.83 \pm 13$ days in Group I and $18.03 \pm 10$ days in Group II. There are studies reporting shorter ${ }^{[4,5]}$ and longer $^{[1,6-8]}$ mean hospitalization durations. The hospitalization duration and surgical intervention rate increased as the total body burn percentage increased.

Hot fluids were the most common cause of pediatric burns followed by flame and electrical burns in the literature. ${ }^{[2,5,8-12]}$ Although scalding burns were the most common type in both groups, flame burns were 2.13 times, electrical burns 3.44 times, flame+inhalation burns 8.33 times, and cases with an over $40 \%$ total burn surface area were 2.41 times more common in Group II than in Group I in our study. Since severe and complicated pediatric burn cases were referred to our clinic from all parts of the country in general to our reference center once the burn center was opened, we expected to see more flame, electrical and inhalation burns in Group II.

The main causes of hot liquid burns in our country are accidents due to children aged I-6 years easily accessing traditional kettles, and accidents during the boiling of milk for cheese and yoghurt production in rural areas as a result of the inappropriate physical environment of the houses of lowincome families. ${ }^{[13]}$ The most common cause was boiled water burns at a rate of $89.92 \%$ in Group I and $81.46 \%$ in Group II in our study. The most common cause of pediatric burn cases in the literature is boiled water at a rate of $48 \%$ to $91 \%{ }^{[1,3,19]}$ Milk burns were more common in Group II than Group I.

Flame burns were found to develop mostly due to tank explosions, accidental ignition of gasoline, and children playing with flammable products and burning fires as a game.

When the cases were investigated according to the total body burn percentages, the most common type in both groups was a burn area of $1-19 \%$. However, the rate of burns of $40 \%$ and above was 2.4I times higher in Group II than in Group I. In conclusion, it was also demonstrated statistically that our clinic received more complicated cases after establishing a pediatric burn center.

Mortality in child burns has decreased significantly with developments in burn treatment. The Shriners Burn Institute has reported $50 \%$ survival rate in cases with $95 \%$ total burn area. [14] Mortality rates of $0.65 \%$ to $15.4 \%$ have previously been reported and the rate is said to significantly increase in flame burns. ${ }^{\left[{ }^{[1]}\right.} \mathrm{A}$ study performed in our country has reported the highest mortality rate among childhood scalding burns as $32.1 \%$ with hot milk burns while the rate for all scalding burns was $10.7 \%$. The most common reasons for mortality were acute kidney failure, sepsis, shock and disseminated intravascular coagulation. ${ }^{[2,4-9,11-13,15-18]}$ While the mean mortality rate for all burns was $1.31 \%$ in our study, it was $0.64 \%$ for scalding burns, $2.35 \%$ for flame burns, $5.88 \%$ for electrical burns and $25 \%$ for flame-inhalation burns. The rate was $18.18 \%$ for burns of $40 \%$ and above surface area. There was no mortality in Group I while this rate was $2.26 \%$ in Group II. Our general mortality rate was lower than reported in the literature but the mortality rates for flame-inhalation burns and for burns with a surface area above $40 \%$ were high.

A study from Iran has reported a mortality rate of $100 \%$ for inhalation burns. ${ }^{[14]}$ The increased mortality was related to the complicated cases with burn surface area over $40 \%$ that required ventilator support and were referred to our center after the burn center became active. We believe our high mortality rate for inhalation burns is due to our relative inexperience in dealing with these patients although we have sufficient theoretical knowledge. 


\section{Conclusion}

A child burn center is the final point in the referral chain of pediatric burn cases. This naturally increases the percentage of admitted flame, inhalation and electrical burn cases with a total burn surface area over $40 \%$ that require ventilator support and advanced knowledge and experience. This is also a training process for the burn team, testing its experience and the ability to cope with much more difficult cases than previously treated. Despite better facilities, the seriousness of the new patient profile accepted for treatment inevitably increases the mortality rate.

\section{Conflict of interest: None declared.}

\section{REFERENCES}

1. Düzgün AP, Senel E, Ozmen MM, Kulaçoğlu H, Işik Y, Coşkun F. The evaluation of the patients admitted to a burn center in Turkey. Ulus Travma Acil Cerrahi Derg 2003;9:250-6.

2. Kobayashi K, Ikeda H, Higuchi R, Nozaki M, Yamamoto Y, Urabe M, et al. Epidemiological and outcome characteristics of major burns in Tokyo. Burns 2005;31 Suppl 1:3-11.

3. Senel E, Polat AD, Yastı AÇ, Karacan CD. In child burns, basic parameters that effect mortality and the precautions. Türkiye Çocuk Hastalıkları Dergisi 2007;1:18-25.

4. Akerlund E, Huss FR, Sjöberg F. Burns in Sweden: an analysis of 24,538 cases during the period 1987-2004. Burns 2007;33:31-6.

5. Bang RL, Sharma PN, Gang RK, Ghoneim IE, Ebrahim MK. Burn mortality during 1982 to 1997 in Kuwait. Eur J Epidemiol 2000;16:731-9.

6. Sakallioğlu AE, Başaran O, Tarim A, Türk E, Kut A, Haberal M. Burns in Turkish children and adolescents: nine years of experience. Burns 2007;33:46-51.

7. De-Souza DA, Marchesan WG, Greene LJ. Epidemiological data and mortality rate of patients hospitalized with burns in Brazil. Burns $1998 ; 24: 433-8$.
8. Yongqiang F, Yibing W, Dechang W, Baohua L, Mingqing W, Ran H. Epidemiology of hospitalized burn patients in Shandong Province: 20012005. J Burn Care Res 2007;28:468-73.

9. Kut A, Basaran O, Noyan T, Arda IS, Akgün HS, Haberal M. Epidemiologic analysis of patients with burns presenting to the burn units of a University Hospital Network in Turkey. J Burn Care Res 2006;27:161-9.

10. Türegün M, Sengezer M, Selmanpakoglu N, Celiköz B, Nişanci M. The last 10 years in a burn centre in Ankara, Turkey: an analysis of 5264 cases. Burns 1997;23:584-90.

11. Goldman S, Aharonson-Daniel L, Peleg K; Israel Trauma Group (ITG). Childhood burns in Israel: a 7-year epidemiological review. Burns 2006;32:467-72.

12. Tung KY, Chen ML, Wang HJ, Chen GS, Peck M, Yang J, et al. A sevenyear epidemiology study of 12,381 admitted burn patients in Taiwan-using the Internet registration system of the Childhood Burn Foundation. Burns 2005;31 Suppl 1:12-7.

13. Aldemir M, Kara IH, Girgin S, Güloglu C. Factors affecting mortality and epidemiological data in patients hospitalised with burns in Diyarbakir, Turkey. S Afr J Surg 2005;43:159-62.

14. Karimi H, Montevalian A, Motabar AR, Safari R, Parvas MS, Vasigh M. Epidemiology of paediatric burns in Iran. Ann Burns Fire Disasters 2012;25:115-20.

15. Haberal M, Ugar N, Bayraktar U, Ener Z. Analysis of 1005 burn patients treated in our centre. Ann. Medit. Burns Club 1993;6:2.

16. Thombs BD, Singh VA, Milner SM. Children under 4 years are at greater risk of mortality following acute burn injury: evidence from a national sample of 12,902 pediatric admissions. Shock 2006;26:348-52.

17. Muqim R, Zareen M, Dilbag, Hayat M, Khan Mİ. Epidemiology and outcome of burns at Khyber Teaching Hospital Peshawar. Pak J Med Sci 2007;23:3.

18. Vehmeyer-Heeman M, Tondu T, Van den Kerckhove E, Boeckx W. Application of cerium nitrate-silver sulphadiazine allows for postponement of excision and grafting. Burns 2006;32:60-3.

19. Senel E, Yasti AC, Reis E, Doganay M, Karacan CD, Kama NA. Effects on mortality of changing trends in the management of burned children in Turkey: eight years' experience. Burns 2009;35:372-7.

\section{ORİJINAL ÇALIŞMA - ÖZET}

\section{Türkiye'de çocuk yanık merkezi olmanın sonuçları}

\section{Dr. Can İhsan Öztorun, Dr. Sabri Demir, Dr. Müjdem Nur Azılı, Dr. Atilla Şenaylı, Dr. Ziya Livanelioğlu, Dr. Emrah Şenel}

Ankara Çocuk Sağıı̆ı ve Hastalıkları Hematoloji, Onkoloji Eğitim ve Araştırma Hastanesi, Çocuk Cerrahisi Kliniği, Ankara

AMAÇ: Hastanemizde çocuk yanık merkezi Ağustos 2009'da kuruldu. Bu çalışmanın amacı, yanık tedavi merkezi kurulmadan önceki ve kurulduktan sonraki hasta profillerini ve verileri karşılaştırmaktır.

GEREÇ VE YÖNTEM: Ocak 2005 ile Ağustos 2009 tarihleri arasında yanık hastaları çocuk cerrahisi servisine kabul edilmekteydi ve bu serviste yoğun bakım hizmeti verilmiyordu. Ağustos 2009 tarihinden itibaren hastanemizde kurulan yanık merkezinde ise yoğun bakım hizmeti de verilmeye başlandı. İlk dönemde serviste takip edilen toplam 316 olgu Grup I, ikinci dönemde yanık merkezine kabul edilen toplam 442 olgu ise Grup II olarak tanımlandı ve bu iki grup arasındaki veriler karşılaştıııldı.

BULGULAR: Grup I'de olguların yaş ortalaması 5.I yıl; Grup II'de 7.7 yıldır. Toplam vücut yanık yüzdesi ortalaması Grup l'de \% 16.12, Grup II'de \% I7.54 tür. Her iki grupta da en sık haşlanma yanıkları görülmekle birlikte Grup I ile karşılaştırıldığında Grup Il'de alev yanıklarının 2.13 kat elektrik yanıklarının 3.44 kat ve alev + inhalasyon yanıklarının 8.33 kat ve toplam yanık yüzey alanının \%40'ın üzerinde olduğu olguların 2.41 kat daha fazla oranda görüldüğü tespit edildi. Mortalite oranları Grup l'de \%0, Grup Il'de ise \%2.26 bulundu.

TARTIŞMA: Yanık ünitesi formatında hasta kabul edilen bir servisten yanık merkezine dönüş, çok daha ağır olguların kabul edilmesini getirmektedir. Bu ise yanık ekibinin bir yandan bu yeni hasta profili ile mücadele ettiği diğer yandan daha önce hiç karşısşmadığı hasta kayıplarını daha az travma ile atlatmayı öğrendiği yeni, sabır ve dikkat gerektiren bir süreci getirmektedir. Bu aynı zamanda tüm yanık ekibi için gerçek bir eğitim sürecidir. Anahtar sözcükler: Çocuk yanıkları; mortalite; yanık merkezi.

Ulus Travma Acil Cerrahi Derg 2016;22(1):34-39 doi: 10.5505/tjtes.2015.464I7 